IZA DP No. 6854

Russian Jewish Immigrants in the United States: The Adjustment of their English Language Proficiency and Earnings in the American Community Survey

Barry R. Chiswick

Nicholas Larsen

September 2012 


\title{
Russian Jewish Immigrants in the United States: The Adjustment of their English Language Proficiency and Earnings in the American Community Survey
}

\author{
Barry R. Chiswick \\ George Washington University \\ and IZA \\ Nicholas Larsen \\ University of Illinois at Chicago
}

Discussion Paper No. 6854

September 2012

\author{
IZA \\ P.O. Box 7240 \\ 53072 Bonn \\ Germany \\ Phone: +49-228-3894-0 \\ Fax: +49-228-3894-180 \\ E-mail: iza@iza.org
}

Any opinions expressed here are those of the author(s) and not those of IZA. Research published in this series may include views on policy, but the institute itself takes no institutional policy positions.

The Institute for the Study of Labor (IZA) in Bonn is a local and virtual international research center and a place of communication between science, politics and business. IZA is an independent nonprofit organization supported by Deutsche Post Foundation. The center is associated with the University of Bonn and offers a stimulating research environment through its international network, workshops and conferences, data service, project support, research visits and doctoral program. IZA engages in (i) original and internationally competitive research in all fields of labor economics, (ii) development of policy concepts, and (iii) dissemination of research results and concepts to the interested public.

IZA Discussion Papers often represent preliminary work and are circulated to encourage discussion. Citation of such a paper should account for its provisional character. A revised version may be available directly from the author. 


\section{ABSTRACT \\ Russian Jewish Immigrants in the United States: The Adjustment of their English Language Proficiency and Earnings in the American Community Survey}

Compared to other immigrants to the United States, recent Jewish immigrants from the former Soviet Union have achieved high levels of English language proficiency and earnings. They experience disadvantages in both dimensions at arrival, but because of steeper improvements with duration in the United States, they reach parity or surpass the English proficiency and earnings of other immigrants. This pattern is seen in the most recent data, the American Community Survey, 2005 to 2009, which is studied here, but also in earlier censuses (1980-2000). The Russian Jews, whether male or female, have higher levels of schooling and English proficiency. Moreover, they appear to secure greater earnings payoffs in the US labor market from their schooling, their labor market experience in the US, and their proficiency in English. What is perhaps remarkable is that the Russian Jewish immigrants from the late 19th and early 20th centuries (1881 to 1920's) also experienced high levels of human capital accumulation and economic success (measured by earnings or occupational attainment). And their US-born children achieved even greater successes compared to other native-born children. This is not emerging from a highly selective immigrant population. The Russian Jewish migration is a mass migration influenced, in part, by refugee motivations. This leads to the obvious but still unanswered question: What is it about the Jews of the Former Russian Empire/Soviet Union that has resulted in their high levels of success in the United States over the past 25 years?

JEL Classification: F22, J61, J31, J24

Keywords: Soviet Jews, immigrants, earnings, schooling, English language, proficiency, American Community Survey

Corresponding author:

Barry R. Chiswick

Department of Economics

George Washington University

2115 G Street, NW Monroe Hall 340

Washington, DC 20052

USA

E-mail: brchis@gwu.edu 


\section{Introduction}

The post-World War II Russian-speaking Jewish immigrant population of the United States is trivial compared to the US population, small (2 percent) compared to the immigrant population as a whole, and is even small compared to the American Jewish population (about 5 percent). The study of their adjustment in the US, therefore, requires data from surveys that specifically target this population, or provide a very large sample of the Jewish, immigrant, or entire US population. Surveys specific to the Russian Jewish population typically lack data on others to provide a comparative perspective. The most recent National Jewish Population Survey (NJPS) was conducted in 2000/2001, and is now over ten years old. Although the sample size is about 5,000 households, it too has a relatively small number of Russian Jewish immigrant respondents. The Public Use Microdata Samples (PUMS) from the 1980, 1990 and 2000 U.S. Censuses of Population provided sufficiently large samples for a comparative analysis of Russian Jews with other immigrants ${ }^{1}$. The 2010 Census, however, did not include the "long form" which was the basis for creating the 1980 - 2000 PUMS data. Rather, the American Community Survey (ACS), conducted monthly, was

\footnotetext{
${ }^{1}$ Barry R. Chiswick, "Soviet Jews in the United States: An Analysis of their Linguistic and Economic Adjustment,” Journal of Population Economics, Vol. 11, No. 2 (Summer 1993), pp. 260-285

Barry R. Chiswick, "Soviet Jews in the United States: Language and Labor Market Adjustments Revisited,” in Noah Lewin-Epstein, Yaacov Ro’I and Paul Ritterbands, eds., Russian Jews on Three Continents: Migration and Resettlement, (London: Frank Cass Publishers, 1997), pp. 233260

Barry R. Chiswick and Michael Wenz, "The Linguistic and Economic Adjustment of Soviet Jewish Immigrants in the United States, 1980-2000,” in Solomon W. Polachek, Carmel Chiswick, Hillel Rapoport, eds. Research in Labor Economics: The Economics of Immigration and Diversity, Vol. 24 (2006), pp. 179-216
} 
implemented to provide a continuous record of the demographic and economic features of American households, rather than the once-in-a-decade snapshot provided by the decennial Census PUMS data.

This essay uses the five year cumulative 2005-2009 American Community Survey (ACS) to examine the linguistic adjustment to English and labor market earnings of adult male and female Russian Jewish immigrants in the United States compared to other immigrants.

The first step in such an analysis is the definition of who is a Russian Jewish immigrant. The ACS, following the pattern of other Census Bureau surveys and censuses, does not include a question on religion. ${ }^{2}$ Moreover, any response to the question on the person's ancestry that would reveal the respondent's religion is masked. Thus, there is no direct mechanism for identifying Russian Jews. An indirect technique is used here, as has been used in previous studies. Immigrants living in the US who were born in the Former Soviet Union (FSU) are assumed to be Jewish, unless they report their ancestry as Armenian or report that the language other than English they currently speak at home is either Armenian or Ukranian. Without doubt this definition will exclude some Russian Jews, but more so it will include non-Jews among the Russian Jews.

\footnotetext{
${ }^{2}$ There are only two exceptions. The Census Office, the forerunner of the Census Bureau, conducted an 1890 survey of 10,000 Jewish households (Billings, John S (1890). Vital Statistics of Jews in the United States, Census Bulletin, No. 19, Washington, D.C., December 30, 1890). The March 1957 Current Population Survey, conducted by the Census Bureau for the Bureau of Labor Statistics, included a question on religion in which Jews could be identified (US Bureau of the Census (1958) "Religion Reported by the Civilian Population of the United States: March 1957" Current Population Reports, Population Characteristics, Series P-20, No. 79, February 2, 1958, Washington, D.C.). Microdata files do not exist for either survey.
} 
The ACS records country of birth and the year the respondent came to the United States to stay. There is no information on when the respondent left the country of origin or if there were sojourns in other countries before entry into the US.

\section{Russian Jewish Immigration}

Data on immigration to the United States from the Russian Empire, the Soviet Union and the states that had comprised the former Soviet Union, over the period of US record keeping (1820-present), exhibit two large waves. The first large wave (see Table 1) was from the 1880s through the 1920s when nearly 3.3 million immigrated $(3,298,821)$. In the second large wave, from the 1980 s to 2009 , over 600,000 people immigrated $(620,223)$. Not all of these immigrants were Jews.

At the start of the first large wave there was concern over the adjustment to the United States and the likely economic attainment of the Russian Jewish immigrants who comprised the larger part of the migrants from the Russian Empire. Could these East European Yiddish speaking, predominantly religiously observant people from an economically backward part of Europe make a successful adjustment to the industrializing United States? ${ }^{3}$ Moreover, this was a mass migration of people fleeing not only economic deprivation, but also religious discrimination and at times religious persecution. These concerns were

\footnotetext{
${ }^{3}$ The Jewish immigrants tended to be less religiously observant in the US than their kinsmen who did not immigrate, but were more observant of Jewish customs and laws than were the German Jews in the US at the time who immigrated primarily from the 1840 s to the 1860 s.
} 
unfounded as the immigrants became very successful in the US. How successful has been the adjustment of the smaller second wave?

Most international migration streams are composed of a relatively small proportion of the origin population, and are motivated by strictly economic concerns. Where this occurs the migrants tend to be "positively selected" for economic success in the destination. Positively selected means they have the characteristics, whether measurable or not, for being successful in adjusting to their new country. In large part their positive selectivity arises from the most able having the greatest economic benefits from migrating (self selectively). That is, the most able would tend to get a greater return on their decision to leave home, family and friends, and their familiar surroundings, than those who remain behind. Depending on time and place, some of this positive selectivity also arises from the destination government's immigration policy—selecting immigrants on the basis of health status, language fluency, work skills or some other characteristics that are deemed desirable. This favorable selectivity is likely to be less intense in mass migrations and among refugees. Among mass migrations many who might otherwise not emigrate get caught up in the flow joining family and friends on the journey. Among refugees, the fear of suffering harm if they stay propels movement even if the conventional economic incentives are not there.

Thus, it would be expected that a migration that has the two characteristics of being a mass migration and having refugee (or at least partial refugee) motives would, on average, tend to have a poorer adjustment in the destination. Yet in 
spite of their initial disadvantages, the first mass migrants of Jews from the Russian Empire, and their children, demonstrated remarkable success compared to other immigrants and the US born. Earnings, as reflected in the few data sources available for that period, and the more readily available data on occupational attainment, primarily from the US Census, but from other sources as well, have been studied ${ }^{4}$. At arrival the Russian Jewish immigrants in the first large wave had relatively poor English language skills and earnings but quickly experienced rapid increases in language skills, their earnings and occupational status. They quickly reached parity with, and then surpassed, those of other immigrants and even of the native born. And their US-born children achieved even higher levels of success in education, earnings and occupations ${ }^{5}$

During the period of the first large wave of Russian Jewish immigrants to the United States, most of the emigrants came to the United States, although some went to Canada, Palestine, Western Europe, and elsewhere. In the second, and recent, large wave the majority of emigrants from the former Soviet Union went to Israel, particularly after the fall of the Soviet Union opened the exit doors widely. Although the Russian Jewish immigrants to the US in this wave were less numerous, constituted a smaller percentage of the Jews exiting the FSU, and came to a country with a larger and well established Jewish population, they are still best characterized as a mass, rather than a selective migration, exhibiting refugee characteristics. Indeed with the collapse of the Soviet Union and the exit door

\footnotetext{
${ }^{4}$ Barry R. Chiswick, “The Occupational Attainment and Earnings of American Jewry, 18901900,” Contemporary Jewry, Vol. 20, (1999) pp. 68-98.

${ }^{5}$ Ibid.,
} 
now wide open many left in fear that the repression of the FSU might quickly return and the exit doors might soon be shut once again.

Research using the 1980, 1990 and 2000 US Censuses of Population has demonstrated a consistent pattern across time ${ }^{6}$. The Jews from the former Soviet Union have a very high level of schooling. Yet at arrival in the US (those in their first few years living in the US) exhibit very low English language skills and earnings. However, their English language proficiency and earnings increase more rapidly with duration in the US than do other immigrant groups, and in not too many years overtake the language proficiency of other immigrants, and overtake the earnings of other immigrants and the native born, even when controlling statistically for educational attainment and other variables.

An analysis of the earnings among American Jews age 25 to 64 years old in the 2000/2001 National Jewish Population Survey (NJPS) can be found in Chiswick and Huang (2008) ${ }^{7}$. Jews from the former Soviet Union had earnings in 1999/2000 significantly lower than US born Jews, and earnings lower than other Jewish immigrants who were predominantly economic migrants, as distinct from the refugee nature of the Soviet Jews. While Jewish immigrants from countries other than the former Soviet Union who had been in the US 20 to 25 years reached earnings parity with US born Jews, in 2000 it was too soon to determine

\footnotetext{
${ }^{6}$ Ibid., Chiswick 1993, Chiswick 1997, Chiswick and Wenz 2006

${ }^{7}$ Barry R. Chiswick and Jidong Huang, "The Earnings of American Jewish Men: Human Capital, Denomination, and Religiosity,” Journal for the Scientific Study of Religion, Vol. 74, No. 4 (December 2008), pp. 694-709.
} 
whether FSU Jews who immigrated in 1981 to 2009 would have the same experience.

Has this pattern that existed in the late $19^{\text {th }}$ and throughout much of the $20^{\text {th }}$ century persisted into the early $21^{\text {st }}$ century? Are the immigrants born in the former Soviet Union who arrived in the US since 2000 exhibiting the same initial poor language skills and earnings potential, and are they likely to achieve success?

\section{The Dependent Variables}

The first dependent variable is this essay is the dichotomous variable for good English. "Good English” is designated by unity if the respondent reports speaking only English at home, or, if another language is spoken, the respondent reports speaking English “very well” or "well.” If English speaking ability is reported as "not well” or "not at all (or only a few words)" the good English variable is set equal to zero. While there are measurement issues in self-reported English language proficiency, there is no particular reason for believing the measurement errors are biased differently between Russian Jewish and other immigrants. In the absence of alternative data on destination language proficiency in immigrant receiving countries, self-reported proficiency has become the standard used in the literature on the economics of language.

The respondent's annual earnings are measured as the sum of last year's wage, salary and self-employment income. The logarithm of earnings, rather than earnings itself, is used by labor economists as the dependent variable in analyses 
of earnings. The structure of the earnings equation that comes from an identity has the natural logarithm of earnings as the dependent variable. Using the natural logarithm of earnings, the coefficients of the explanatory variables have economic interpretations, and the regression equation residuals have nicer statistical properties (closer to a normal distribution and to being homoskedastic) ${ }^{8}$. While wage and salary incomes cannot be negative, self-employment income can. Because natural logarithms cannot be taken of zero or negative numbers, annual earnings that sum to $\$ 1,000$ or less (including negative values) are assigned a value of $\$ 1,000$. The earnings data are adjusted for inflation so that the earnings are in 2009 dollars.

\section{The Econometric Models}

As in the previous studies of the English language adjustment to the US of Russian Jews, the explanatory variables include ${ }^{9}$ :

(1) Age at Migration - Other variables the same, research in linguistics and economics shows that immigrant destination language proficiency is lower with an older age at immigration. The age effect is steeper among youths and teenagers, but tends to level off among older immigrants. The ability to adapt to a new language appears to weaken at older ages. Consistent with the refugee

\footnotetext{
${ }^{8}$ Jacob Mincer, "Schooling, Earnings, and Experience,” (New York: National Bureau of Economic Research, 1974)

${ }^{9}$ For the development of the model for destination language proficiency and its effects on earnings across several destination countries, see Chiswick and Miller (2007). For earlier studies of the English language proficiency of Russian Jews in the U.S., see Chiswick 1993, 1997 and Chiswick and Wenz 2006.
} 
characteristics of the Russian Jewish immigrants, they arrived in the US at an older age. $^{10}$

(2) Schooling - The education effect is measured by years of schooling. Immigrants with more schooling have been found to be more proficient in the dominant language in the destination, perhaps because those with higher levels of intellectual ability are more proficient in learning new languages and attain more schooling. It may also be that those who attain higher levels of schooling in the origin are more likely to be exposed to the English language in school, and hence schooling level and English proficiency are positively related. ${ }^{11}$ Since the data do not identify the country in which schooling was obtained, it might be that schooling in the US is associated with greater English language proficiency, either because English proficiency is a prerequisite for US schooling, or because the US schooling experience enhances English proficiency.

(3) Years Since Migration - Duration in the destination measured in years is a simple measure of exposure to the language of the destination. The longer the duration, the more time there is to acquire destination language skills ("learning by living”), although it is expected that the greatest impact would occur in the

\footnotetext{
${ }^{10}$ Age at arrival of immigrants (mean) 2005-2009 American Community Survey: Males Females

Russian Jews 28.7

$\begin{array}{ll}\text { Other immigrants } & 22.2 \\ \end{array}$

${ }^{11}$ Note, however that among immigrants in Israel, Hebrew language proficiency is also associated with higher levels of secular schooling, even though Hebrew language instruction or exposure is not likely to increase with higher levels of schooling (Chiswick, 1988).
} 
early years, with the marginal effect diminishing as time passes. Hence, duration is treated as a quadratic variable.

(4) Married Spouse Present - A marital status variable is included in the model to establish whether being married (or in a cohabitating relationship) is associated with greater proficiency. It also indicates whether the marriage effect differs by gender. If marriage encourages specialization in labor market vs. home production activities, it may enhance the proficiency of men, but decrease that of women. (5) Children (kids) -The presence of a child in the household is entered in the language equation for women. Children are associated with a lower labor force participation rate for women and hence less of an incentive to acquire English language proficiency and less of an opportunity for exposure to English in the workplace.

(6) Jewish - A dichotomous variable for being Jewish, defined as above, is included in the regression analysis. Tests were conducted for interaction terms between being Jewish and other explanatory variables, in particular schooling and duration in the destination.

The equation is modified in the analysis of earnings. In the analysis of earnings a human capital earnings function is employed. The dependent variable is the natural logarithm of the sum of wage, salary and self-employment income in the previous year. The explanatory variables include:

(1) Schooling - Years of schooling enters into the analysis as a measure of labor market skills. 
(2) Labor Market Experience - Labor market experience (EXP) is not directly reported in the ACS, but the standard proxy for potential experience is usedyears since leaving school, measured as age minus years of schooling minus five. Experience and its square are entered into the equation to account for the nonlinear effect on earnings of labor market experience. Earnings increase with experience, but at a decreasing rate.

(3) South - Because of the generally lower earnings in the Southern states (17 states, including the District of Columbia), a dichotomous variable for living in the South is included in the equation.

(4) English Proficiency (GoodEnglish) - The English language proficiency variable is included as a determinant of earnings. Immigrants more proficient in the destination language are expected to be more successful in finding a job, more likely to have a better match of their other skills to the job they find, and to be more productive on the job. Hence, they are expected to receive higher earnings. (5) Years Since Migration - A longer duration in the destination is expected to result in more efficient labor market networks, and more skills relevant for the destination labor market. The effect will be non-linear (earnings increasing with duration at a decreasing rate) as greater investments in destination skills and knowledge are made in the earlier years, and diminish thereafter.

(6) Marital Status - Marital status is included in the analysis as married men appear to have a stronger labor market attachment than never-married men, and more able (higher earning) men are more likely to be successful in the marriage market (i.e., more likely to be married). Marriage is associated with a lower labor 
supply for women, hence less labor market experience in the past, and therefore lower earnings currently. Those in a cohabitating relationship are treated as married.

(7) Children (kids) - The presence of one or more children in the household is associated with lower past female labor supply and hence lower earnings for women.

(8) Weeks Worked -The variable for the natural logarithm of weeks worked is entered largely as a standardizing variable since the dependent variable is the natural logarithm of annual earnings. A coefficient greater than unity implies that those with higher weekly earnings work more weeks in the year. This may arise from those with higher weekly earnings wanting to work more (upward rising labor supply curve) or those who work more hours in a week also work more weeks in the year. Seasonal employment implies fewer weeks worked in the year, but a higher weekly wage during the weeks worked. If immigrants are more likely to be in seasonal employment, the effect of weeks worked on annual earnings will be smaller for the immigrants than for the native born.

The analysis of English language proficiency and of earnings uses the combined American Community Survey 2005-2009. The sample is limited to the males and females, age 25-64 years, who worked in the previous year and had positive (or negative) earnings and who are foreign born (i.e., born outside the US and its territories). 


\section{Data Analysis}

\section{(A) Descriptive Statistics}

Among the foreign born adults who worked in the previous year, the American Community Survey 2005-2009 includes observations on 529,840 males and 432,986 females. The sample is smaller for females because of their lower labor force participation rate. The Russian Jews were $1.6 \%$ of the men $(8,575$ observations) and $2.2 \%$ of the women (9,447 observations) in part because of a higher Russian Jewish female labor force participation rate. The Russian Jewish men had a shorter duration in the US (YSM), 14.3 years compared to 20.0 years for the immigrant men in general. This reflects the time pattern of immigration. The Russian Jewish men have higher levels of skill than the immigrant men in general--15.6 years of schooling compared to 12.6 years, and an 84 percent English language proficiency rate compared to a 75 percent proficiency. They are more likely to be married (77 percent compared to 69 percent). More schooling, greater proficiency in English and more likely to be married would all have a positive effect on the earnings of Russian Jewish men, compared to other men, but the shorter duration in the U.S. would have an opposite effect. Adjusted for inflation the annual earnings of the Russian Jewish men (measured in 2009 dollars) were $\$ 65,400$, compared to $\$ 51,900$ for all the immigrant men.

Among women who worked in the previous year, the Russian Jews have been in the US for an average of 13.5 years, compared with 20.9 years for the foreign born women in general. The Russian Jews have 15.6 years of schooling in contrast to the 13.1 years for all female immigrants who worked. Proficiency in 
English was greater among the Jews (87 percent proficient, compared to 78 percent) and they were more likely to be currently married (73 percent compared to 65). Reflecting their lower level of fertility, 41 percent lived in a household with at least one child, while this was the situation for 46 percent of all women.

Again, their higher level of schooling and greater English language proficiency, as well as their smaller family size, would be expected to enhance their earnings compared to other immigrant women, but their recent arrival would have an opposite effect. Adjusted for inflation the Russian Jewish women had annual earnings of $\$ 43,100$, compared to $\$ 34,600$ for all of the foreign born women.

(B) Analysis of English Language Proficiency

In the analysis of English Language Proficiency (Table 2), among both men and women, and for Russian immigrants and all immigrants, proficiency is more prevalent the higher the level of schooling, the longer the duration of residence in the US (at a decreasing rate), the younger the age at migration and, among women, if there are no children in the household. Being married has a positive association with proficiency, except among Russian immigrant men among whom there is no effect.

The survey year dichotomous variables are of mixed signs and have small coefficients even when statistically significant compared to the benchmark year 2009. This means that there have been no trends in proficiency across the period (2005-2009) when other variables, including duration in the US, are held constant. 
When Russian Jewish men are compared with the other male immigrants (Table 2), proficiency among Jews increases more rapidly with duration in the US, but increases less rapidly with higher levels of schooling. At the mean values of duration and schooling those identified here as Russian Jews are essentially on par with other immigrants (-0.013 lower proficiency). The steeper effect of duration is a characteristic associated with a refugee population.

Among the women, however, the patterns are somewhat different. Both a longer duration in the US and higher levels of schooling are associated with less improvement in proficiency among the Russian Jewish women than among the other immigrant women.

\section{(C) Analysis of Earnings}

Among all men and women and Russian Jewish men and women who worked last year, weekly earnings increased with level of schooling, proficiency in English, duration in the US, and living outside the southern states (Table 3). Pre-immigration labor market experience (i.e., total experience when duration in the US is held constant) had a small positive effect on earnings for men, but a small negative effect for women. Married men earned substantially more than men not currently married (about 20 percent more). The marriage effect was negative and small for Russian Jewish women, and positive but trivial (1 percent) for all immigrant women. For both groups of women the presence of children in the household had a negative effect on their earnings (about 4 percent). 
Among both the men and women, on average the Russian Jews had greater earnings than the other immigrants, other variables being the same (by 26.7 percent for men and by 24.8 percent for women). Also among the men and the women the effect of schooling and duration in the US on earnings was significantly greater among the Russian Jews. ${ }^{12}$ Moreover the effect of weeks worked on annual earnings, while greater than unity for all groups, was larger for the Russian Jews ${ }^{13}$.

Another dimension of human capital relevant for the United States is English language proficiency. Russian Jewish immigrant men receive a larger return (by 5 percent) from English proficiency, than other immigrants, while among women there is no difference between the two groups. ${ }^{14}$

\footnotetext{
${ }^{12}$ Difference in partial effects of schooling and years since migration. Males Females $0.034 \quad 0.024$ Schooling 0.034

$\begin{array}{ll}(11.5) & 0.012 \\ 0.006 & (12.0)\end{array}$

Years Since Migration

t-ratios in parentheses, from pooled regressions with Russian Jewish interaction terms.

Source: Table 3, Columns (1) and (3)

${ }^{13}$ Partial effect of the natural logarithm of weeks worked on the natural logarithm of annual earnings

$\begin{array}{lrr} & \text { Males } & \text { Females } \\ \text { Russian Jews } & 1.083 & 1.153 \\ \text { All Immigrants } & (49.8) & (65.7) \\ & 1.017 & 1.100 \\ & (380.6) & (472.0)\end{array}$

t-ratios in parentheses, from pooled regressions. Source: Table 3, Columns (1) to (4)

${ }^{14}$ Partial effects on earnings of Good English:

Males Females

Russian Jews $\quad 0.300 \quad 0.249$

(11.8) $\quad(9.5)$

All Immigrants $\quad 0.234 \quad 0.241$

(82.6) $\quad(70.0)$
}

t-ratios in parentheses, from pooled regressions. Source: Table 3, columns (1) to (4) 
These differences are not merely statistically significant; they are also generally quite large. Moreover, they are consistent with comparative analyses of earnings among US-born Jews and other native-born Americans. Jews appear to have a larger return from schooling, which would of course encourage a higher schooling attainment. They also appear to receive a larger benefit from labor market experience in the US, which may be due to greater investment in the US labor market training, a greater rate of return from this investment, or more likely, both.

Thus, whether the form of human capital is formal schooling, US labor market experience, or English language proficiency, Russian Jews receive larger returns in the US labor market than do other immigrants.

The earnings data have been adjusted for inflation and are in 2009 dollars. The dichotomous survey year variables show the difference in real weekly earnings (i.e., annual earnings controlling for weeks worked) from the benchmark survey 2009. The effects of the recession are shown by the statistically significant decline in real weekly earnings in 2008 and 2009 compared to 2005 to 2007, by about 4 percent among all immigrants (regression coefficients not shown).

\section{Summary and Conclusions}

Compared to other immigrants to the United States, recent Jewish immigrants from the former Soviet Union (referred to here as Russian Jews) have achieved high levels of English language proficiency and earnings. They experience disadvantages in both dimensions at arrival, but because of steeper 
improvements with duration in the United States, they reach parity or surpass the English proficiency and earnings of other immigrants. This pattern is seen in the most recent data, the American Community Survey, 2005 to 2009, which were studied here, but also in earlier censuses (1980-2000).

The Russian Jews, whether male or female, have higher levels of schooling and English proficiency. Moreover, they appear to secure greater earnings payoffs in the US labor market from their schooling, their labor market experience in the US, and their proficiency in English. That is, they are more successful in generating earnings from their human capital.

What is perhaps remarkable is that the Russian Jewish immigrants from the late 19th and early 20th centuries (1881 to 1920's) also experienced high levels of human capital accumulation and economic success (measured by earnings or occupational attainment). And their US-born children achieved even greater successes compared to other native-born children.

This is not emerging from a highly selective immigrant population. In both periods the Russian Jewish migration is a mass migration influenced, in part, by refugee motivations. This leads to the obvious but still unanswered question: What is it about the Jews of the Former Russian Empire/Soviet Union that has resulted in their high levels of success in the United States over the past 125 years?

*We appreciate the research assistance of Marina Gindelsky 


\section{References:}

(1) Billings, John S (1890). Vital Statistics of Jews in the United States, Census Bulletin, No. 19, Washington, D.C., December 30, 1890.

(2) Chiswick, Barry R. (1988) “Hebrew Language Usage: Determinants and Effects on Earnings Among Immigrants in Israel” Journal of Population Economics, Vol 11, No. 2, pp 253-271.

(3) Chiswick, Barry R. (1993). "Soviet Jews in the United States: An Analysis of their Linguistic and Economic Adjustment”, International Migration Review, Vol 27, No. 2, Summer, pp 260-285.

(4) Chiswick, Barry R. (1997). "Soviet Jews in the United States: Language and Labor Market Adjustments Revisited” in Noah Lewin-Epstein, Yaacov Ro’i and Paul Ritterband, eds., Russian Jews on Three Continents: Migration and Resettlement, London: Frank Cass Publishers, pp. 233260.

(5) Chiswick, Barry R. (1999) “The Occupational Attainment and Earnings of American Jewry, 1890-1990” Contemporary Jewry, Vol 20, pp. 68-98.

(6) Chiswick, Barry R. and Jidong Huang (2008). "The Earnings of American Jewish Men: Human Capital, Denomination and Religosity" Journal for the Scientific Study of Religion, 74, 4, December, 694-709.

(7) Chiswick, Barry R. and Paul W. Miller (2007). The Economics of Language: International Analyses, London, Routledge

(8) Chiswick, Barry R. and Michael Wenz (2006). “The Linguistic and Economic Adjustment of Soviet Jewish Immigrants in the United States, 
1980-2000”, in Solomon W. Polachek, Carmel Chiswick, Hillel Rapoport, eds, The Economics of Immigration and Diversity, Special Issue of Research in Labor Economics, Vol 24, 179-216.

(9) Micer, Jacob (1974) Schooling, Earnings and Experience, New York: National Bureau of Economic Research

(10) US Bureau of the Census (1958) "Religion Reported by the Civilian Population of the United States: March 1957” Current Population Reports, Population Characteristics, Series P-20, No. 79, February 2, 1958, Washington, D.C. 
Table 1. Immigration to the United States from Russia and the Former Soviet

Union, 1820-2009a

\begin{tabular}{lr}
\hline Time Period & Number of Immigrants \\
\hline $1820-1830$ & 89 \\
$1831-1840$ & 277 \\
$1841-1850$ & 551 \\
$1851-1860$ & 457 \\
$1861-1870$ & 2,512 \\
$1871-1880$ & 39,284 \\
$1881-1890$ & 213,282 \\
$1891-1900$ & 505,290 \\
$1901-1910$ & $1,597,306$ \\
$1911-1920$ & 921,201 \\
$1921-1930$ & 61,742 \\
$1931-1940$ & 1,370 \\
$1941-1950$ & 571 \\
$1951-1960$ & 671 \\
$1961-1970$ & 2,465 \\
$1971-1980$ & 38,961 \\
$1981-1990$ & 57,677 \\
$1991-2000$ & 462,874 \\
$2001-2009$ & 149,672 \\
Total & \\
\hline
\end{tabular}

Source: US Department of Justice, 1993 Statistical Yearbook of the Immigration and Naturalization Service, Washington, D.C., September 1994; US Department of Justice, 2001 Statistical Yearbook of the Immigration and Naturalization Service, Washington, D.C., February 2003; and US Department of Homeland Security, 2002 Yearbook of Immigration Statistics, Washington, D.C., October 2003.

US Department of Homeland Security, 2009 Yearbook of Immigration Statistics, Washington, D.C., August 2010.

${ }^{a}$ Individuals granted permanent resident alien status. Includes all constituent units of the Russian Empire and of the Former Soviet Union, except for the Baltic Republics for 2001-2009. 
Table 2: Analysis of English Language Proficiency Among Foreign-Born Adult Males/Females and Russian Jewish Adult Males/Females

American Community Survey, 2005-2009

(Dependent Variable: GoodEnglish)

Variable

(1)

(2)

(3)

(4)

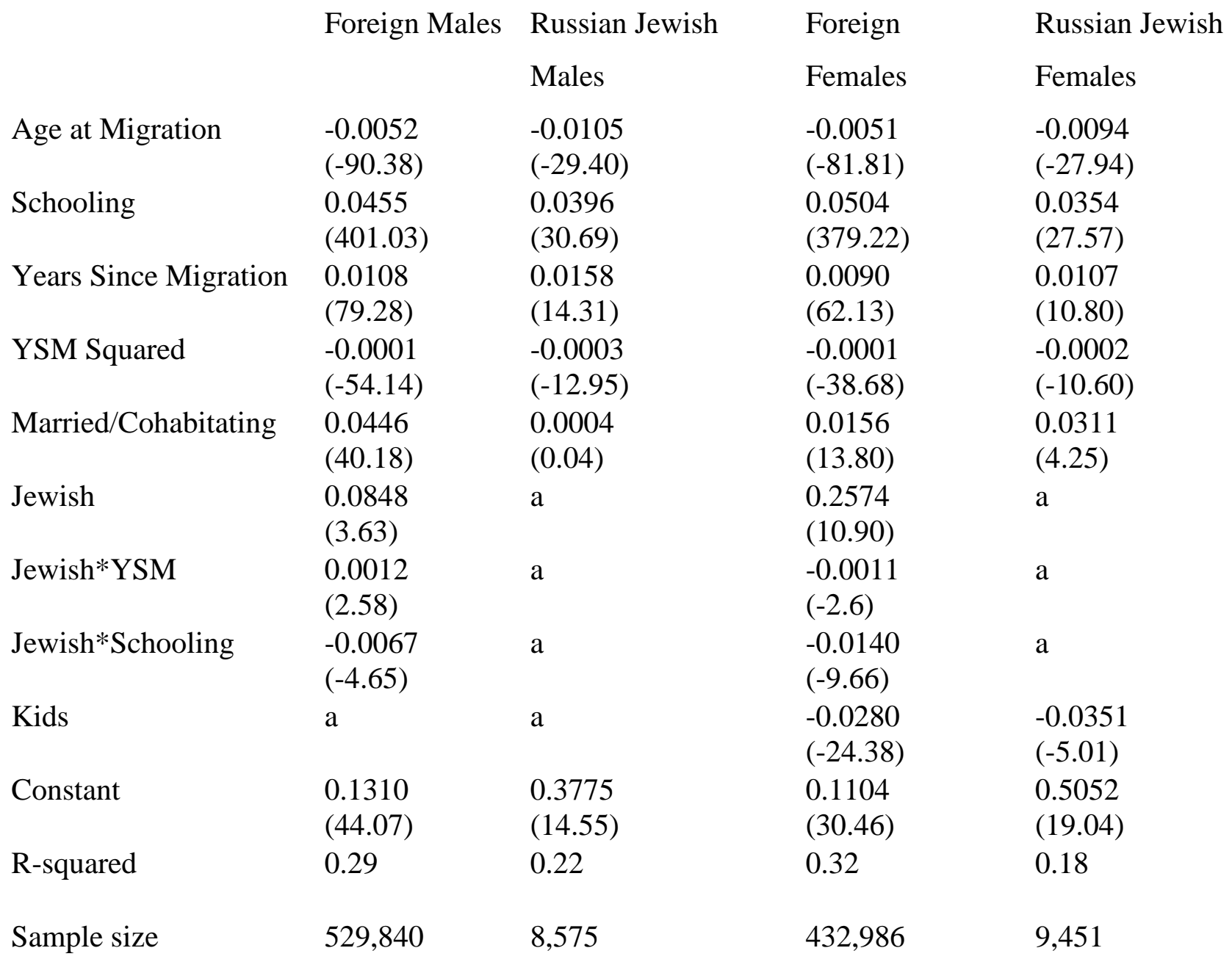

Notes: Foreign born persons age 25 to 64 years who worked in the prior year.

t-ratios in parentheses

$\mathrm{a}=$ Not included in equation

Source: U.S. Bureau of the Census, American Community Survey, PUMS, 2005-2009 
Table 3: Analysis of Earnings Among Foreign-Born Adult Males/Females and Russian Jewish Adult Males/Females, American Community Survey, 2005-2009 (Dependent Variable: Natural Logarithm of Earnings, in 2009 dollars))

\begin{tabular}{|c|c|c|c|c|}
\hline \multirow[t]{3}{*}{ Variable } & (1) & (2) & (3) & (4) \\
\hline & \multirow[t]{2}{*}{ Foreign Males } & Russian Jewish & Foreign & Russian Jewish \\
\hline & & Males & Females & Females \\
\hline Schooling & $\begin{array}{l}0.0683 \\
(237.1)\end{array}$ & $\begin{array}{l}0.08953 \\
(27.94)\end{array}$ & $\begin{array}{l}0.0731 \\
(187.56)\end{array}$ & $\begin{array}{l}0.0871 \\
(24.51)\end{array}$ \\
\hline GoodEnglish & $\begin{array}{l}0.2336 \\
(82.62)\end{array}$ & $\begin{array}{l}0.3002 \\
(11.84)\end{array}$ & $\begin{array}{l}0.2410 \\
(69.96)\end{array}$ & $\begin{array}{l}0.2494 \\
(9.46)\end{array}$ \\
\hline Experience & $\begin{array}{l}0.0121 \\
(30.06)\end{array}$ & $\begin{array}{l}0.0088 \\
(2.56)\end{array}$ & $\begin{array}{l}-0.0011 \\
(-2.45)\end{array}$ & $\begin{array}{l}-0.0022 \\
(-0.69)\end{array}$ \\
\hline Exp. Squared & $\begin{array}{l}-0.0002 \\
(-22.93)\end{array}$ & $\begin{array}{l}-0.0031 \\
(-4.28)\end{array}$ & $\begin{array}{l}-0.0000 \\
(-3.48)\end{array}$ & $\begin{array}{l}-0.0001 \\
(-1.02)\end{array}$ \\
\hline Years Since Migration & $\begin{array}{l}0.0131 \\
(47.38)\end{array}$ & $\begin{array}{l}0.0375 \\
(14.06)\end{array}$ & $\begin{array}{l}0.1934 \\
(59.57)\end{array}$ & $\begin{array}{l}0.0589 \\
(22.23)\end{array}$ \\
\hline YSM squared & $\begin{array}{l}-0.0001 \\
(-26.39)\end{array}$ & $\begin{array}{l}-0.0005 \\
(-8.84)\end{array}$ & $\begin{array}{l}-0.0003 \\
(-43.24)\end{array}$ & $\begin{array}{l}-0.0009 \\
(-15.28)\end{array}$ \\
\hline Married/Cohabitating & $\begin{array}{l}0.2118 \\
(92.13)\end{array}$ & $\begin{array}{l}0.1861 \\
(9.14)\end{array}$ & $\begin{array}{l}0.0093 \\
(3.63)\end{array}$ & $\begin{array}{l}-0.0384 \\
(-2.05)\end{array}$ \\
\hline South & $\begin{array}{l}-0.0633 \\
(-28.98)\end{array}$ & $\begin{array}{l}-0.0402 \\
(-1.81)\end{array}$ & $\begin{array}{l}-0.0862 \\
(34.06)\end{array}$ & $\begin{array}{l}-0.0749 \\
(-3.62)\end{array}$ \\
\hline Ln weeks worked & $\begin{array}{l}1.0168 \\
(380.64)\end{array}$ & $\begin{array}{l}1.0830 \\
(49.77)\end{array}$ & $\begin{array}{l}1.1004 \\
(472.02)\end{array}$ & $\begin{array}{l}1.1530 \\
(65.72)\end{array}$ \\
\hline Jewish & $\begin{array}{l}-0.5582 \\
(-11.63)\end{array}$ & a & $\begin{array}{l}-0.5044 \\
(-9.45)\end{array}$ & $\mathrm{a}$ \\
\hline Jewish*School & $\begin{array}{l}0.0338 \\
(11.48)\end{array}$ & $\mathrm{a}$ & $\begin{array}{l}0.0242 \\
(7.36)\end{array}$ & $\mathrm{a}$ \\
\hline Jewish*YSM & $\begin{array}{l}0.0058 \\
(6.21)\end{array}$ & $\mathrm{a}$ & $\begin{array}{l}0.0115 \\
(12.04)\end{array}$ & $\mathrm{a}$ \\
\hline Kids & $\mathrm{a}$ & a & $\begin{array}{l}-0.0470 \\
(-17.33)\end{array}$ & $\begin{array}{l}-0.0351 \\
(-1.88)\end{array}$ \\
\hline Constant & $\begin{array}{l}5.0144 \\
(424.81)\end{array}$ & $\begin{array}{l}4.3820 \\
(44.24)\end{array}$ & $\begin{array}{l}4.5467 \\
(397.14)\end{array}$ & $\begin{array}{l}3.895 \\
(43.16)\end{array}$ \\
\hline R-squared & 0.39 & 0.38 & 0.46 & 0.44 \\
\hline Sample size & 529,773 & 8,574 & 432,879 & 9,447 \\
\hline
\end{tabular}


Appendix Table: Descriptive Statistics of the Variables for Foreign Born Males and Females, American Community Survey, 2005-2009

Foreign Born Males
Variable
Total Earnings
Adjusted Total Earnings
Ln Adjusted Total Earnings
Schooling
Good English
Experience
Experience Squared
Years Since Migration (YSM)
YSM Squared
Married/Cohabitating
South
Ln Weeks Worked
Russian Jew Dummy
Russian Jew*Schooling
Russian Jew*YSM
Kids

\begin{tabular}{lrrrr} 
Obs & \multicolumn{1}{l}{ Mean } & Std. Dev & \multicolumn{1}{l}{ Min } & \multicolumn{1}{l}{ Max } \\
529773 & 50120.43 & 59979.36 & 1000 & 1023000 \\
529773 & 51905.52 & 61977.52 & 996.205 & 1019118 \\
529773 & 10.43106 & 0.9487923 & 6.903953 & 13.8345 \\
529840 & 12.55314 & 4.455114 & 0 & 20 \\
529840 & 0.7544693 & 0.4304018 & 0 & 1 \\
529840 & 24.66217 & 11.04732 & 0 & 59 \\
529840 & 730.2657 & 597.7684 & 0 & 3481 \\
529840 & 19.96805 & 12.63607 & 1 & 65 \\
529840 & 558.393 & 640.1446 & 1 & 4225 \\
529840 & 0.6885682 & 0.4630793 & 0 & 1 \\
529840 & 0.3279575 & 0.4694697 & 0 & 1 \\
529840 & 3.800422 & 0.3855145 & 1.94591 & 3.93183 \\
529840 & 0.0161841 & 0.1261833 & 0 & 1 \\
529840 & 0.2519091 & 1.994686 & 0 & 20 \\
529840 & 0.23073 & 2.113063 & 0 & 62 \\
529840 & 0 & 0 & 0 & 0
\end{tabular}

\begin{tabular}{rrrrr} 
Obs & Mean & Std. Dev & \multicolumn{1}{l}{ Min } & Max \\
8574 & 63245.47 & 65939.11 & 1000 & 889000 \\
8574 & 65429.15 & 67941.72 & 996.205 & 919655 \\
8574 & 10.69561 & 0.9637081 & 6.903953 & 13.7318 \\
8575 & 15.56519 & 2.736867 & 0 & 20 \\
8575 & 0.8362682 & 0.3700536 & 0 & 1 \\
8575 & 22.42991 & 10.84838 & 0 & 59 \\
8575 & 620.7746 & 520.6171 & 0 & 3481 \\
8575 & 14.25656 & 8.714236 & 1 & 62 \\
8575 & 279.1785 & 401.7348 & 1 & 3844 \\
8575 & 0.7686297 & 0.4217331 & 0 & 1 \\
8575 & 0.1659475 & 0.3720552 & 0 & 1 \\
8575 & 3.807388 & 0.3820259 & 1.94591 & 3.93183 \\
8575 & 1 & 0 & 1 & 1 \\
8575 & 15.56519 & 2.736867 & 0 & 20 \\
8575 & 14.25656 & 8.714236 & 1 & 62 \\
8575 & 0 & 0 & 0 & 0
\end{tabular}




\section{Foreign Born Females}

Variable

Total Earnings

Adjusted Total Earnings

Ln Adjusted Total Earnings

Schooling

Good English

Experience

Experience Squared

Years Since Migration (YSM)

YSM Squared

Married/Cohabitating

South

Ln Weeks Worked

Russian Jew Dummy

Russian Jew*Schooling

Russian Jew*YSM

Kids

\begin{tabular}{lrrrr} 
Obs & Mean & \multicolumn{1}{c}{ Std. Dev } & \multicolumn{1}{l}{ Min } & \multicolumn{1}{l}{ Max } \\
432879 & 33454.4 & 37815.63 & 1000 & 943000 \\
432879 & 34622.2 & 39019.2 & 996.205 & 939421.3 \\
432879 & 9.99122 & 1.048673 & 6.903953 & 13.75302 \\
432986 & 13.0555 & 3.996994 & 0 & 20 \\
432986 & 0.78101 & 0.4135645 & 0 & 1 \\
432986 & 24.8079 & 11.22164 & 0 & 59 \\
432986 & 741.357 & 598.6077 & 0 & 3481 \\
432986 & 20.8834 & 12.83514 & 1 & 65 \\
432986 & 600.855 & 666.5431 & 1 & 4225 \\
432986 & 0.64756 & 0.4777317 & 0 & 1 \\
432986 & 0.31845 & 0.4658753 & 0 & 1 \\
432986 & 3.70967 & 0.5109703 & 1.94591 & 3.931826 \\
432986 & 0.02183 & 0.1461202 & 0 & 1 \\
432986 & 0.3415 & 2.314252 & 0 & 20 \\
432986 & 0.29541 & 2.332582 & 0 & 61 \\
432986 & 0.46263 & 0.4986024 & 0 & 1
\end{tabular}

Russian Jews Females
Variable
Total Earnings
Adjusted Total Earnings
Ln Adjusted Total Earnings
Schooling
Good English
Experience
Experience Squared
Years Since Migration (YSM)
YSM Squared
Married/Cohabitating
South
Ln Weeks Worked
Russian Jew Dummy
Russian Jew*Schooling
Russian Jew*YSM
Kids

\begin{tabular}{rrr} 
Obs & Mean & \multicolumn{1}{c}{ Std. Dev } \\
9447 & 41694.8 & 44586.7 \\
9447 & 43089.6 & 45869.93 \\
9447 & 10.2386 & 1.03124 \\
9451 & 15.6452 & 2.436711 \\
9451 & 0.87176 & 0.334375 \\
9451 & 21.9487 & 10.87065 \\
9451 & 599.903 & 513.4191 \\
9451 & 13.534 & 8.372895 \\
9451 & 253.268 & 370.4457 \\
9451 & 0.73548 & 0.4411018 \\
9451 & 0.18718 & 0.3900734 \\
9451 & 3.74995 & 0.4635845 \\
9451 & 1 & 0 \\
9451 & 15.6452 & 2.436711 \\
9451 & 13.534 & 8.372895 \\
9451 & 0.41128 & 0.4920917
\end{tabular}

Min 1000
996.205
6.903953
0
0
0
0
1
1
0
0
1.94591
1
0
1
0

Max

867000

922340.4

13.73467

20

1

59

3481

61

3721

1

1

3.931826

Note: Foreign-born males and females age 25 to 64 years who worked in the previous year. Adjusted Total Earnings means earnings adjusted for price differences in each year, expressed in 2009 dollars.

Source: American Community Survey, PUMS, 2005-2009 